\title{
The Examination of The Main Transportation Arteries of Konya In Terms of Landscape Architecture Design Criteria
}

\author{
Sertaç Güngör*Ahmet Tuğrul Polat
}

Department of Landscape Architecture, Faculty of Agriculture, University of Selcuk, 42075 Konya, Turkey

\section{A R T I C L E I N F O \\ Research Article \\ Received 07 December 2016 \\ Accepted 14 February 2017}

Keywords:

Pedestrian

Sidewalk

Landscape design

Transportation arteries

Konya/Turkey

A B S T R A C T

Ensuring comfort of use and security of pedestrians, which are the main users of urban green spaces, and the determination of their needs are important since local authorities are guiding for new pedestrian zone studies in the Konya city. Because of the problems caused by the upper structure, the necessary care is not given in terms of transportation comfort, pedestrian safety, vehicle security, plant design and ergonomic / antropemetric standards. The pedestrian way and refuge landscape designs have an important position and amount among open green areas on the scale of Konya. However, it was identified that the applications conducted were inadequate in terms of aesthetic and functional characteristics and were not suitable for the urban landscape design principles, in general, and the standards of urban afforestation of the streets. In this study, the current situation of 3 main streets of Konya used most intensely was examined in terms of landscape design criteria and some suggestions were made by attempting to identify the improvement works that should be performed by the public authorities.

*Corresponding Author:

E-mail: sertac@ selcuk.edu.tr

\section{Introduction}

Nowadays, longing for nature and green in cities, developing in an unplanned and an unhealthy way, gradually increases in parallel with the increase in population. In this regard, open green areas and trees, which are the basic component of these areas, emerging among the concrete structure of the cities have a significant position in balancing the damaged relationship between human and nature and in the improvement of urban living conditions (Küçük and Gül 2005).

According to Castillo-Manzano et al. (2014); there is worldwide interest in analyzing pedestrianization and traffic calming processes and it is evidently a 'hot topic' in urban studies in both developed and developing countries. Studies in the EU can be cited in the first case, principally Germany, (Hass-Klau, 1984, 1993; Ward, 2010) and the UK (Turner and Giannopoulos, 1974; Whitehead et al., 2006), and others in the United States (Ahn and Rakha, 2009; Giuliani et al., 1997; Robertson, 1993). With regard to the developing countries, the studies that focus on Asia stand out mainly, those on Turkey (Dokmeci et al., 2007), Iran (Iranmanesh, 2008), Hong Kong (Yiu, 2011), India (Samuel, 2013), Indonesia (Lo, 2010), Malaysia (Ghahramanpouri et al., 2012) and Singapore (Yuen and Chor, 1998).

Tree selection should be a priority as the trees are often identified as a signature for the area. Proper selection, installation, and maintenance of trees are a major consideration for street landscape projects. It is important to be familiar with tree species including its characteristics, irrigation requirements, mature size, rooting habits, and maintenance requirements. Shrub and groundcover selection is important as well. Shrub and groundcover plantings can add dimension, seasonal color, and soften hardscapes in street median areas (Anonymous, 2006).

Transportation access not only an access for vehicles, but in it also covers an access for pedestrians to enter open space, access to work, access to the services area, access to shopping centers, etc. (Mauliani et al., 2014).

Pedestrian zones are the places which all strata of the society frequently use during the day and in which they spend most of their time outdoors. Some functions of pedestrian ways and central refuge landscape designs are as follows (Öztürk, 1998):

Street Landscape is designed and installed to provide a community with an aesthetic transportation corridor.

- Urban street plantations undertake functions regarding traffic engineering in the matters of guidance, emphasizing certain spots, limiting the driver's area of interest, shadowing the standing traffic, the security of pedestrians, preventing negative outlooks in the vertical and horizontal directions, connecting/separating structures and places along the road. 
- Trees are easy to remember since they create a clear contrast with structures. Thus, they make it easy for strangers to find directions in the city.

- They are significant for car drivers on roads which especially allow speed in the city in terms of security and navigation.

- Drivers are warned by trees before the traffic signs and find the opportunity to adjust their speed in time. This effect can be ensured by using different species or planting distances in street plantation.

- It is possible to indicate dead ends, intersections, junctions and pedestrian crossings by trees.

- They help focus the driver's attention on the road by camouflaging the factors which create confusion such as sandwich boards, light boards, and show windows on main roads in cities.

- They are effective in separating pedestrian spaces, which need to be far from the negative effects of vehicle traffic, and other uses on urban roads.

- Especially bushy plants, used for separating vehicle and pedestrian traffic, create a safety element in terms of pedestrians by slowing down the vehicles which can swerve in the case of any accident.

- The trees planted consecutively side by side create a passage effect.

- They provide shade for vehicles, especially in parking lots.

- They prevent the noise from echoing within the space in the places surrounded by structures and deprived of trees.

- Thickset wide crowned trees create a ceiling effect in street plantations. Furthermore, deciduous trees have a feature of enlarging the space (Öztürk 1998).

Especially in the design of aesthetic and functional spaces, plants, undoubtedly, undertake significant roles. Thus, firm, stiff, dull and lifeless appearances of the material forming the landscape such as stone, asphalt, concrete, iron, etc. can be rendered more natural and humane only with the materials which display a lively, cute, soft and warm look such as plants. Plants provide these activities with their dynamics in the course of time and only grow, flourish, display their own movements and bring the fourth dimension to the landscape within the course of time. The dendrologic characteristics and morphological features of plants such as size, shape, color, and texture as well as their adapting to the environmental conditions should be taken into consideration in the use of plants in green spaces and they should be positioned in accordance with the intended use. Only in this way, aesthetically and functionally suitable designs can be performed and the desired result can be reached (Önder and Polat, 2000).

According to pedestrian rights declaration, urban centers are pedestrian zones and are the true owners of urban life. Thus, pedestrianship is supported and motivated since it increases communication among people and contributes to the urban culture. According to pedestrian rights declaration 1990 (Anonymous, 1990), pedestrians develop an organization with the local government which will advocate pedestrian rights and transmit their complaints. In traffic-related decisions, the police also observe and protect the rights of pedestrians. Local governments make the pedestrian infrastructure, day-night maintained, clean and bright, restored, with visual appeal with plants and trees, with the contributions of the Pedestrians. Pedestrians have the right to participate in decision-making regarding pavements, pedestrian zones, pedestrian ways, and pedestrian crossings. Every citizen has these rights for a civilized, habitable, humane and healthy place (Şişman and Uyguner, 2009).

Concept of pedestrian way should has some elements which will support its function. An element of pedestrian should be helped by providing others elements to interact with. Those elements should be related to the environment, urban planning and activities' patterns which should be adjusted to the development and planning for the future (Mauliani et al., 2014).

This research was done to investigate whether the most important three street of Konya have been planted in accordance with the landscape design criteria.

\section{Material and Method}

Street plantation works which Konya Metropolitan Municipality Parks and Gardens Department has carried out constitute the study material. In order to determine the study area, study tours have been carried out on urban streets in 2016 and Halil Ürün, Yeni Meram and Nalçacı streets, which are among the most important main arteries of the city, have been chosen as sampling areas. (Konya's longest and most widely used avenues have been selected for that.)

The research method consisted of various stages.

At the first stage, the current positive/negative situation was revealed by the observations carried out in accordance with the ecological, functional and aesthetic design criteria of urban roads.

In the second stage, observations, measurements and counts were made in the field of research to determine the current situation. The type and species identifications and health conditions of the landscape plants of the three streets composing the study area were also exhibited.

At the final stage, various proposals were attempted to be brought by means of the photographs taken on the spot regarding Konya, municipality activity reports, the interviews with the employees of Konya Metropolitan Municipality Parks and Gardens Department and the employees of Konya Metropolitan Municipality Directorate of Technical Works.

\section{Findings}

Street plantations on roads and refuges occupy a significant place as a number of trees and surface area within Konya open green spaces. The information about the streets on which studies were carried out is given below. 


\section{Doç. Dr. Halil Ürün Street}

The length of the street, which begins from the bus terminal and reaches the bus terminal bridge crossing (the end of Barıs Street), is approximately $1.7 \mathrm{~km}$. The width of the street, except for the central refuge, is approximately $24 \mathrm{~m}$. The material type of the street is asphalt. This street has a very wide refuge. The refuge width is $45 \mathrm{~m}$ at the widest section and $5 \mathrm{~m}$ at the narrowest section. The pavement width is approximately $3 \mathrm{~m}$. Figure 1 shows the satellite image of the street and pictures taken from the marked places A and B.

Deciduous tree species used in the central refuge and pedestrian way are Plantanus orientalis, Pyracantha coccinea, Cornus alba, Cotonaster dammeri, Prunus cerasifera "Atropurpurea", Acer spp. Evergreen species such as Picea abies, Abies nordmanniana, Cedrus deodora, Picea pungens, Cedrus libani, Juniperus Sabina were also used.

In the current plants on the street, exist pests such as cochineal in Prunus cerasifera "Atropurpurea", scale insects in Acer negundo and Evonymous japonica, red spider in Tilia ssp., pollen spurt in Platanus orientalis (detrimental to asthma patients), aphid in Catalpa bignonoides. Moreover, potassium deficiency (Acording to Anonymous 2016, potassium deficiency symptoms usually occur in older leaves first. Because the newly formed young leaves are done in case of lack of support from older leaves potassium. Deficiency symptoms begin to appear before the edges of the leaves in many plants and terminals. Before the leaves turn yellow edges, and then turns into a dark brown color in these parts) is observed in Aesculus ssp. and Aces pseudoplatanus. A disease called Ceroplastes Rusci is observed in Prunus cerasifera and Cedrus deodora "Glauca". Thus, necessary precautions should be taken for these diseases and pests by Konya Metropolitan Municipality Parks and Gardens Department.

Major issues observed on the street are as follows;

Thick-textured and bottom branching species should be used in the central refuge to diminish a headlight effect due to the busy usage of the street at night. However, there are not enough low bushes which will ensure that the driver will not be disturbed by the headlight in the central refuge.

Medium-density evergreen plants are used on the street. The use of coniferous plants is a wrong preference on such a heavily used street with the opening of the new stadium because especially evergreen species are negatively affected by the exhaust gases from vehicles. Deciduous species such as Acer campestre, Acer platanoides, and Aesculus hippocastanum are also affected negatively by the exhaust gases.

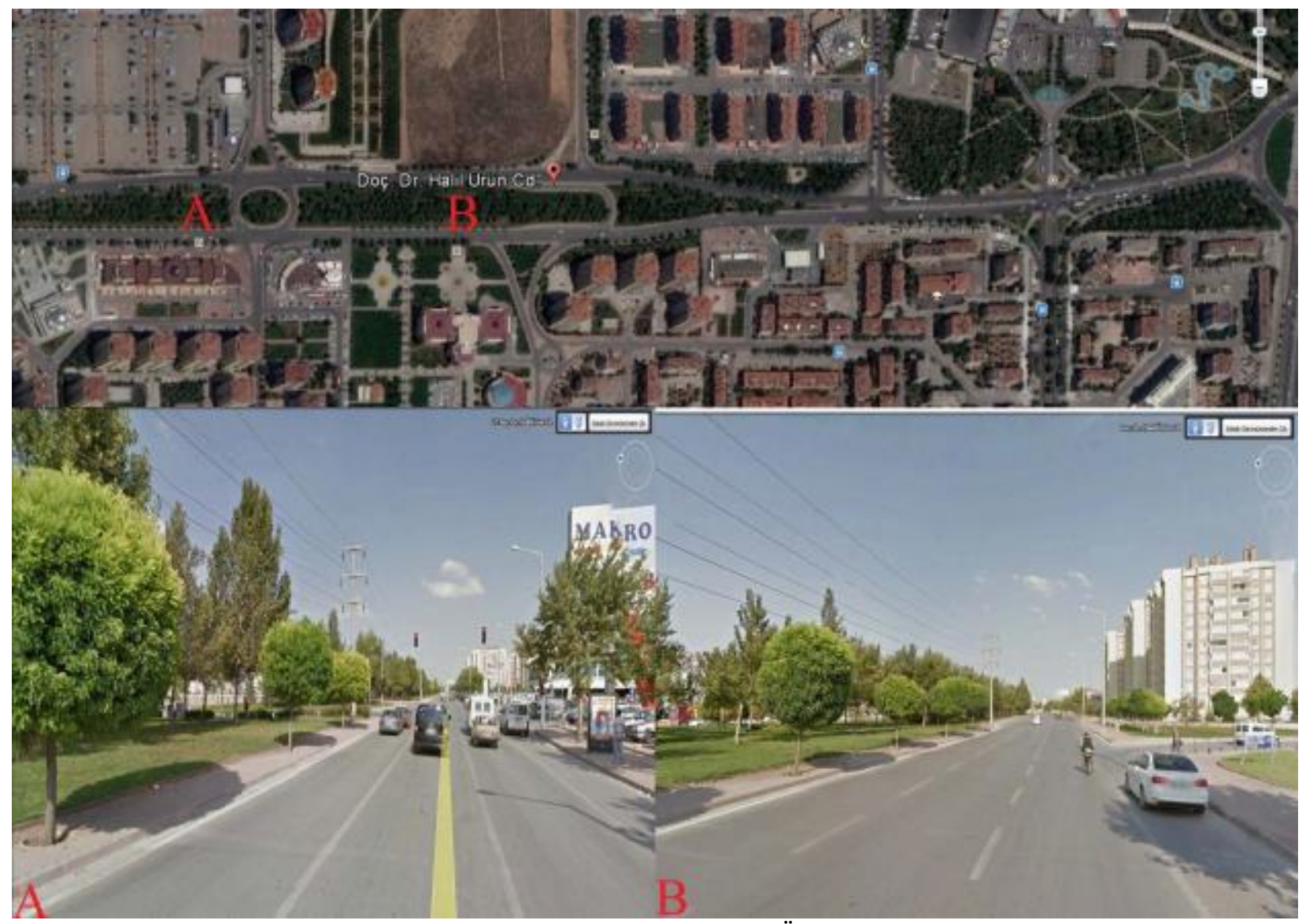

Figure 1 Google view of Halil Ürün street. 
Two people cannot walk side by side in the pavement section of the central refuge allocated for pedestrians. Pavements were not designed of sufficient width in terms of anthropometrical standards .

Besides, Acacia ssp. is located on the walkway. These trees render pedestrian access difficult due to the fact that the height of their crown sections from the ground is shorter than $172 \mathrm{~cm}$ (beginning of the branching of an ideal pedestrian walk tree).

The plants were planted in the central refuge along a straight line in order to be watered easily with drip irrigation. This weakens the visual effect of the plants aesthetically.

The pedestrians crossing the street damage the grass in the central refuge because of the insufficient pedestrian roads in the central refuge. Stepping stones or interlocking paving stones need to be paved on the passes which pedestrians heavily use. As a result of the observations carried out on the street, it was observed that especially Plane Tree grew inclined due to faulty planting and phototropism (tendency to light). The species with malformation need to be staked and straightened.

\section{Yeni Meram Street}

The length of the street beginning from the underpass (in front of the Military Officer's Club) and reaching Tavus baba is approximately $5,5 \mathrm{~km}$. The width of the street, though varies locally, is $20 \mathrm{~m}$ on average. The refuge width, though non-existent at specific sections, is approximately $1 \mathrm{~m}$. The pavement width, though not the same at every section, is approximately $2,5 \mathrm{~m}$. In certain places, it decreases to $2 \mathrm{~m}$. The material type of the street is asphalt. In the refuge, the firm soil was preferred instead of grass. No cycle lanes exist.

This street was replanned by Konya Metropolitan Municipality Parks and Gardens Department and with the help of Konya Metropolitan Municipality Directorate of Technical Works as of 2008. It became the most prestigious street in Konya. The pavements, curbs, and refuges on the street were completely paved with andesite. The road was widened and passages were rendered more secure at the junction of Yeni Meram Street. Figure 2 shows the satellite image of the street and pictures taken from the marked places $\mathrm{A}$ and $\mathrm{B}$.

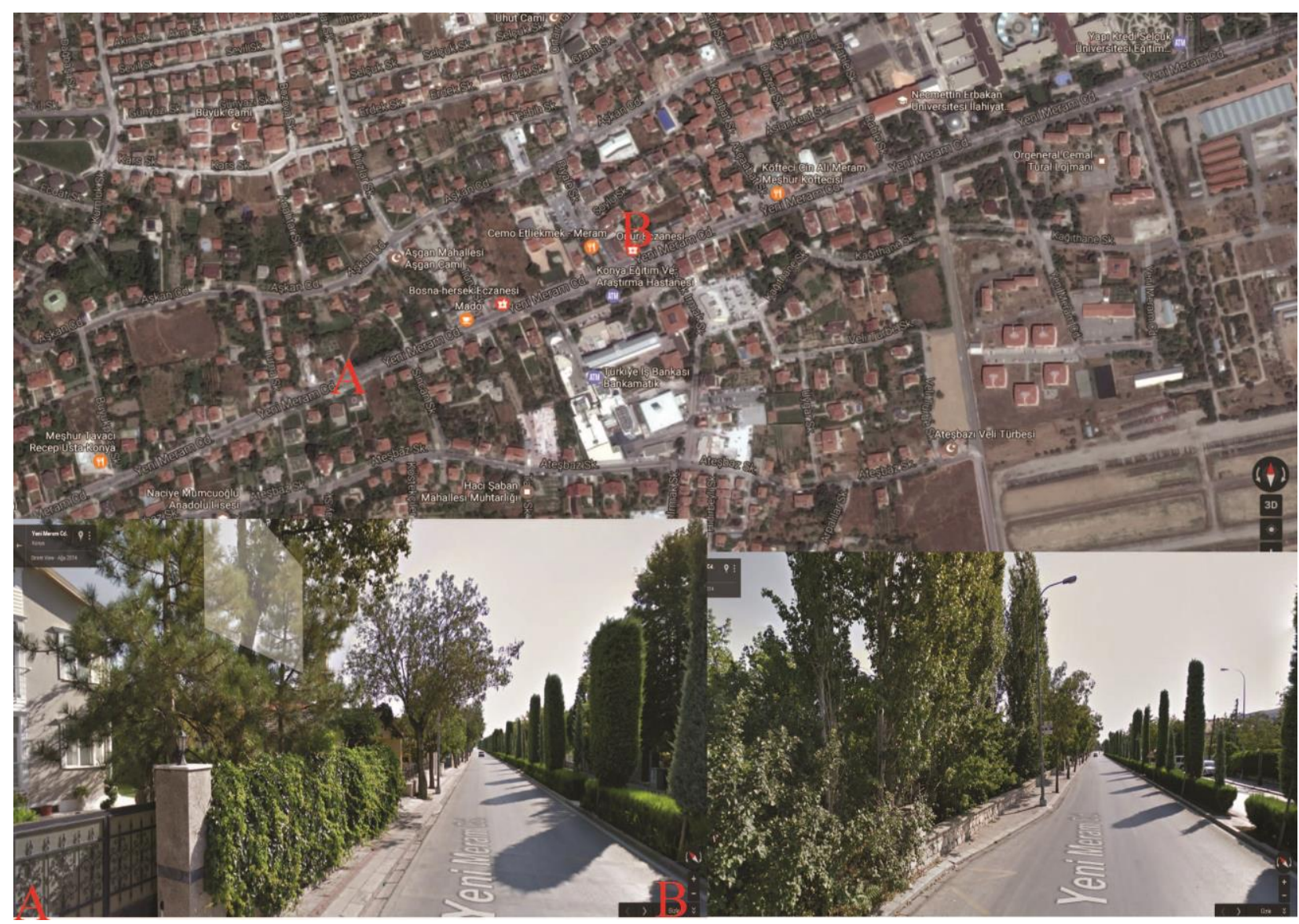

Figure 2 Google view of Yeni Meram street

The central refuge was restructured alternately and Prunus cerasifera 'Atropurpurea', Cupressus sempervirens and locally Thuja orientalis were used. On the pedestrian walk, deciduous species such as Fraxinus excelsior, Robinia pseudoacacia, Tilia rubra, Plantanus orientalis, Catalpa bignonoides, Populus nigra and evergreen species such as Picea abies, Abies nordmanniana, Cedrus libani, Juniperus sabina, Pinus nigra, though a few, were used.

Pests and diseases observed in the current plants on the street are as follows; 
Although the pollen of the poplar tree is forbidden in the city center since it is detrimental to asthma patients, it was used on Yeni Meram Street.

On Yeni Meram Street, pests such as mealybug, scale insect, aphid, trunk worm pests, diazinon, cypermethrin, and malathion exist.

The problems observed on the street are as follows: the trees in the vicinity of the SSK Hospital create unnecessary crowns and prevent vehicles from passing. Besides, the parking problem exists in the section of the hospital which overlooks the street. This problem repeats due to some trees' having a wide crown structure on pedestrian walks, as well.

Cupressus sempervirens was used in the central refuge for the purpose of emphasizing. Since the width of the refuge is narrow, the selection of this species is correct.
However, the cypress species is very high in accordance with the anthropometric measurements. This endangers the safety of power lines.

People drop litter aside the trees and drop cigarette stubs under the trees because of the lack of trash bins on pedestrian roads or insensibleness of people.

\section{Nalçacı Street}

The length of the street from Konya Metropolitan Municipality to Kunduracilar location is approximately 2 $\mathrm{km}$. The width of the street, including the central refuge, is $39 \mathrm{~m}$. The material type of the street is asphalt. The refuge width is approximately $10 \mathrm{~m}$. The width of the pavement is approximately $4 \mathrm{~m}$. Figure 3 shows the satellite image of the street and pictures taken from the marked places $\mathrm{A}$ and $\mathrm{B}$.

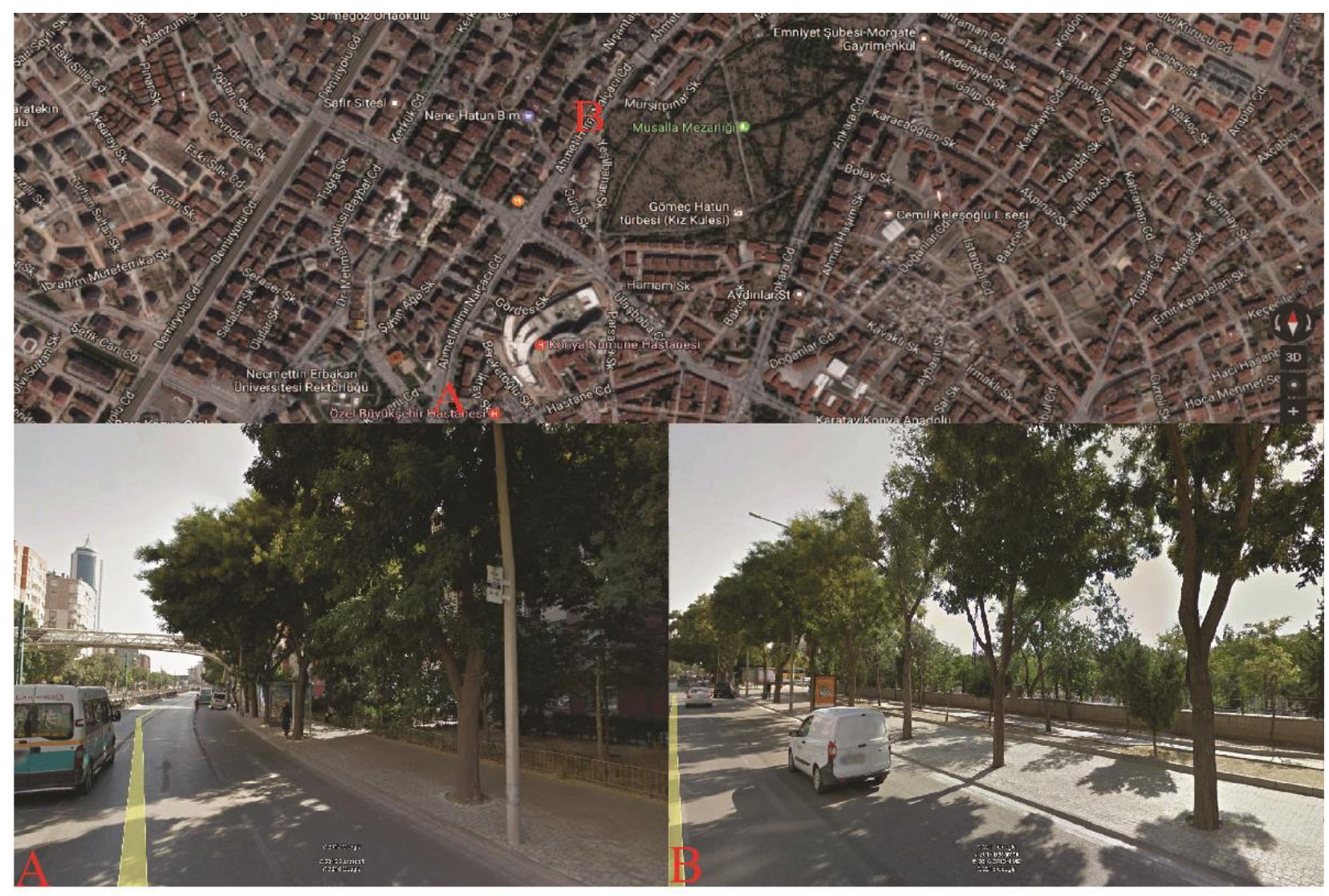

Figure 3 Google view of Nalçacı street

Fraxinus excelsior was heavily used and with this plant, though a few, Prunus cerasifera 'Atropurpurea', Plantanus orientalis, Pinus nigra were used on the pedestrian walk. Since the tram line is on this route, only Cupressus arizonica was used in the central refuge. At the intersections on the way to the Police Station and Sille, Rose spp. was used.

The problems observed on the street;

Fraxinus excelsior was planted too often in such a way that their crowns would interpenetrate. The trouble here is that the crown width of the tree in the following years was not taken into consideration. Hence, on this street, species were selected without knowing the characteristics of the plants and without the dendrologic information required in terms of landscape architecture. In order to overcome such problems, complication can be eliminated by pruning aesthetically and in a way that will not damage the plant.

Thus, while carrying out adjustments on the roads, the factors such as species' ecological desire, height, crown width, suitability to the area should be taken into consideration and most importantly, a feasibility and analysis study regarding the area should be carried out and a design should be created. 
A parking lot with a sufficient capacity was not designed for the banks located in the pedestrian section of the street. Pedestrian accesses are not possible as a consequence of the vehicles' parking on the pavement. Pedestrians who cannot walk on the pavement have to to get down on the roadway and get into danger.

\section{The Evaluation of the Findings}

Pedestrian walk and refuge landscape designs have a significant place among open green spaces on the scale of Konya. However, it was identified that the applications conducted were inadequate in terms of aesthetic and functional characteristics and were not suitable for the Urban Landscape Design Principles (Memlük, 2012), in general, and the Standards of the Urban Afforestation of Streets and Squares (Anonymous, 2016b). The troubles and inadequacies identified in Konya urban street plantations can be summarized as follows:

The responsibility in street plantations has been granted to municipalities. However, municipalities mostly push landscape design works into the background due to the inadequacy of the income sources of municipalities. Moreover, since a direct communication cannot be established between district municipalities and metropolitan municipality, the landscape designs which will be/were carried out cannot be performed in a specific order.

The tree species to be selected should branch out smoothly in terms of morphological and physiological characteristics and at least at the height of 2-2.5 $\mathrm{m}$ in the vertical direction, should not form too thick or curved trunks. The tree species with a weeping shape which do not develop smooth trunks, grow slowly, and develop superficial roots are not suitable for the use on streets and squares. Defoliation periods of non-evergreen species should be short, leaves and fruit should not create a slippery ground on the roads.

The fruit sizes should not be of the dimensions that will endanger the traffic, pollen should not cause allergic diseases in people. The highest branching form which the species to be selected will take in terms of design and urban aesthetics, the color and structure of the leaves, the beginning time and duration of autumn colouration, blooming time and duration, the form and color of fruit, the color and texture of trunk bark should be taken into consideration (Çelem and Uslu, 2006).

The ecological data of the street trees should be suitable for the habitat needs of the tree species to be selected. Species selection in street trees should be determined in accordance with the function of the street. Traffic density which the urban roads harbor, whether the roads are used for recreational purposes or for transportation determine the tree species to be planted (Çelem and Uslu, 2006).

Many street trees are pruned without aesthetic concerns due to their damaging power lines. Thus, street trees and electric poles should be positioned in locations which will not damage one another in the design. Street trees should never cover traffic lights and directions. It should be taken into consideration in the design that traffic lights should be at least at the height of $4.5 \mathrm{~m}$ from the ground (Şahin and Kurum, 2006).

From the administrative perspective, the quality and distribution of technical employees responsible for street trees in the Parks and Gardens Department also pose a problem. The fact that street trees and their habitats have special conditions requires that the people who will work on this subject have special knowledge and skills. In fact, although various service units are created in municipalities, every employee can usually work at every job regarding planning, application, maintenance, repair and manufacture (Bulut, 1997).

It is observed that maintenance works also cannot be carried out in a sufficiently suitable way for the technique in the street plantations conducted. It is identified that maintenance and repair works with regard to improving living conditions of street trees such as ventilating the soil surface on which $\mathrm{t}$ trees are planted, fertilization from above, healing the wounds, filling in the hollows, supporting tree trunks, struggle against insect and fungi attacks cannot be performed in an effective and continuous way. For instance, although planted saplings are supported with a metal or wooden material, broken or removed supports are not replaced with the new ones. Especially very old trees on the urban roads are abandoned to their fates and no works are carried out for their protection.

In addition to the mistakes made on street trees, there are various direct and indirect negative effects of citizens. For instance, they can be listed as follows: plucking tree parts such as branch, sucker, leaf, throwing or pouring hazardous materials on tree roots such as cigarette butts, detergent, oil, the negative effects of some materials on trees such as signboards, show boards, negativities arising from construction works of urban infrastructure and superstructure. All negative effects caused by citizens indicate that the awareness of environmental protection has yet to form. The tendency to damage urban trees is especially frequently seen in children and teenagers. Hence, starting environmental and natural education at early ages bears great importance (Küçük and Gül 2005).

\section{Conclusion and Suggestions}

In Konya street plantations, it should be known that successful and healthy results can be obtained with more rational solution decisions on condition of knowing the current problems and complying with the current Standards of the Urban Afforestation of Streets and Squares.

In street plantations, the locations of roads and squares within the city, the class qualities of the road should be taken into consideration. In the selection of the plantation form and tree species, the current condition of the road and improvement targets should be considered.

Street and square plantation and application projects should be prepared on the same scale with the structure designs along the road which the traffic estimates. Initially, it should be in harmony with the road 
illumination and infrastructure equipment and should determine the form and scale of the plantation. On the streets with a central refuge, if the refuge is narrower than $4 \mathrm{~m}$, no trees should be planted on the refuge. However, in order to decrease mutual headlight effects in comings and goings at night, bushy plants $(0.6-1.2 \mathrm{~m})$ which will not surpass the size of the vehicle can be suggested.

Street trees should not cover traffic lights and direction signs. The height of traffic lights from the ground is $4.5 \mathrm{~m}$. Trees are pruned deeply due to their damaging power lines. Thus, street trees and electric poles should be positioned in a way that they will not damage one another in the design. The illumination of roads is significant in terms of the city safety. However, in faulty applications, tree crowns cannot carry out their functions. In plantations, planting which will prevent illumination should be avoided.

Being symmetrical in terms of the crown structure, suitable for the functions and the environment in terms of the form, size, and structure and having a nice appearance are the reasons for the preference of street trees. Tree species which reflect autumn colors with their changing appearances in accordance with the seasons, with their various colors and beautiful scents and attractive fruits are very effective on city roads and streets.

Since it will create visual confusion, the use of different species at short intervals along the road should not be allowed. The use of different species should mostly be implemented along the road for the purpose of creating a signal effect in emphasizing and directing. For instance, when wider crowned plants are used in pedestrian crossings, traffic speed will decrease since this situation gives the driver the feeling of a narrowing road.

Low saplings which will be used as a street tree should be avoided and there is a great advantage in especially high saplings. It should be ensured that lower branches of the trunk and roots are pruned in time, the trunk is heightened and the roots are frayed.

Defoliation of non-evergreen species should be short, leaves and fruit should not create a slippery ground on the road. The size of fruit should not be of the dimensions that will endanger the traffic. Pollen should not cause allergic diseases in people.

The minimum planting distances should be complied with in order for trees on streets not to be affected by buildings, facilities, and infrastructure. No trees should be planted in the middle of pavements the width of which is narrower than $3 \mathrm{~m}$. Especially broad-leaved tree species should be preferred on narrow pavements. In the refuges narrower than $3 \mathrm{~m}$, bushes and ground covering species should be preferred instead of tree species.

Realizing the planting technique by taking planting rules into consideration, installing irrigation, fertilization, ventilation and drainage shafts or perforated plastic pipes which will be used for this purpose at new facilities during the establishment should not be ignored.

Street trees should not be situated exactly opposite to one another. Trees in the first line should be planted in a way that they will be between the two opposite trees.
The selection of planting distances and illumination elements should be performed in a way that will not hinder the functions of illumination elements.

On urban roads and streets, the planting distances of trees, the crown development, and height of trees, the light need of neighboring structures, the width of the road, benefit expected from trees located within the road space, the durations during which trees will reach the desired height and form should be considered. For this purpose, in general, it is 3-6 $\mathrm{m}$ for narrow crowned trees, 6-8 $\mathrm{m}$ for medium crowned trees, $8-10 \mathrm{~m}$ for big trees.

Konya has been heavily experiencing the negative results of unplanned and faulty applications carried out in the past regarding urban street plantations. Since green spaces were turned into pavements afterwards, evergreen plants which had existed there before remained on the pavement and restricted/prevented the pedestrian access. Since green spaces were asphalted and turned into roads after changing the zoning status, monumental trees which remained on them pose a problem for vehicle safety such as Monumental Tree Number 53 in Meram district.

In Konya, especially evergreen species were widely used on narrow pavements or central refuges in the past landscape designs. Evergreen species which were generally planted as small saplings cannot continue their development under environmental pressures and factors and their natural forms are destroyed and they mostly remain scrub. In fact, coniferous species planted can affect the vehicle traffic negatively. For instance, there are Cedrus libani, Juniperus Sabina and Picea pungens in the central refuge of Doç.Dr. Halil Ürün Street. Species such as "Glauca" were used. Coniferous plants should not be used in the central refuge since they are affected by exhaust gases from vehicles and they are far from the aesthetic and decorative understanding.

Pollen or cankers of many tree species planted in the past such as Populus ssp. and Platanus ssp. (generally in May and June) affect the urban life negatively. For instance, on many streets such as Doç.Dr. Halil Ürün Street, Yeni Meram Street, Meram Yaka Street, Plane trees were used in the central refuge and pedestrian walk. Besides, asthma patients are negatively affected by tree species such as Populus ssp. and Platanus ssp.

Many mistakes and faults can be counted for our city Konya such as the selection and use of the trees which damage the infrastructure with their root systems such as Populus ssp., Salix ssp., and Acacia ssp., allocating the insufficient space for air and irrigation for the root development, trees' not being able to complete their normal development due to the $20 \mathrm{~cm} \times 20 \mathrm{~cm}$ size of root spreading areas, deterioration of the aesthetic effects and functional values of trees due to faulty and unconscious maintenance and pruning works carried out.

It is aimed to shorten the analysis period by sharing the identified problems with the relevant units of the municipality.

It can be ensured that the parks and gardens departments of the metropolitan municipality and district municipalities will make fewer mistakes in the future refuge landscape designs and capture the aesthetic beauty 
as well as functionality by getting support from the department of landscape architecture at the university.

\section{References}

Anonymous. 1990. Yaya Hakları Bildirgesi, İhd 1990. Web page: http://www.yayed.org/id96-incelemeler/yaya-haklari-bildirgesiihd-1990.php

Anonymous. 2006. Street Landscape Standards. Phoenix Parks and Recreation Department. https://www.phoenix.gov/streetssite/ Documents/streetman.pdf [26/01/2017]

Anonymous. 2016. Symptoms of potassium deficiency in plants. http://www.tarimmarketi.com/BitkilerdePotasyumEksikligi.asp $\mathrm{x}[24 / 12 / 2016]$

Anonymous. 2016b. Design Manual for Urban Roads and Streets. Department of Housing, Planning, Community and Local Government, Custom House, Dublin. Web page: http://www.housing.gov.ie/sites/default/files/migratedfiles/en/Publications/DevelopmentandHousing/Planning/FileDo wnLoad\%2C32668\%2Cen.pdf [26/01/2017]

Bulut A. 1997. Kent İçi Yol Ağaçlamasının Tesis Tekniği ve Ankara Örneğinde Sorunları, Çözüm Önerileri, Ankara Üniversitesi Fen Bilimleri Enstitüsü Peyzaj Mimarlığı Anabilim Dalı Yüksek Lisans Tezi, Ankara.

Castillo-Manzano JI, Lopez-Valpuesta L, Asencio-Flores JP. 2014 Extending pedestrianization processes outside the old city center; conflict and benefits in the case of the city of Seville, Habitat International, Volume 44: 194-201, ISSN 0197-3975, http://dx.doi.org/10.1016/j.habitatint.2014.06.005.

Çelem H, Uslu A. 2006. Kent İçi Yol Ağaçlandırma Çalışmaları: Genel Değerlendirme. Kent İçi Ağaçlandırma Çalışmalarında Teknikler ve Sorunlar: Ankara Örneği Panel. 11 Kasım 2006. Kırsal Çevre ve Ormancılık Sorunları Araştırma Derneği. Ankara.
Küçük V, Gül A. 2005. Isparta Kent İçi Yol Ağaçlandırmaları Üzerine Bir Araştırma.Süleyman Demirel Üniversitesi Fen Bilimleri Enstitüsü Peyzaj Mimarlığı Anabilim Dalı Yüksek Lisans Bildirisi, Isparta.

Mauliani L, Purwantiasning AW, Aqli W. 2015. Designing Better Environment by Providing Pedestrian Way for Pedestrian, Procedia - Social and Behavioral Sciences, Volume 179: 80-93, ISSN 1877-0428, http://dx.doi.org/10.1016/j.sbspro.2015.02.412.

Memlük MZ. 2012 Urban Landscape Design, Landscape Planning, Dr. Murat Ozyavuz (Ed.), InTech, DOI: 10.5772/39015. Available from: https://www.intechopen.com/books/landscapeplanning/urban-landscape-design [17/12/2016]

Önder S. Polat AT. 2000. Yollarda Bitkisel Tasarım İlkeleri; Konya Kenti Örneği. Kentsel Yeşil Dokunun Analizi ve Bakım Esaslar1 Semineri, Sayfa:78-92. Konya.

Öztürk B. 1998. Kent İçi ve Kent Dışı Karayolu Ulaşım Sisteminde Bitkilendirmenin Trafik Tekniği Yönünden İşlevleri. EGM Trafik Hizmetleri Başkanlığı Trafik Araştırma Merkezi Müdürlüğü Araştırma İnceleme Raporları. URL: http://www.trafik.gov.tr/icerik/bildiriler/A1-62.doc [05/10/2016]

Şahin Ş, Kurum E. 2006. Kent İçi Yol Ağaçlandırmasında Planlama ve Tasarım. Kent İçi Ağaçlandırma Çalışmalarında Teknikler ve Sorunlar: Ankara Örneği Panel. 11 Kasım 2006. Kırsal Çevre ve Ormancılık Sorunları Araştırma Derneği. Ankara.

Şişman EE, Uyguner B. 2009. Tekirdağ Kent Merkezinde Kullanıcıların Yaya Bölgeleri Hakkındaki Görüşlerinin Belirlenmesi. Süleyman Demirel Üniversitesi Orman Fakültesi Dergisi Seri: A, 2: 134-146 